\title{
Curriculum as a Vehicle for Agency in Gifted Learners
}

\author{
Madelaine Armstrong Willcocks
}

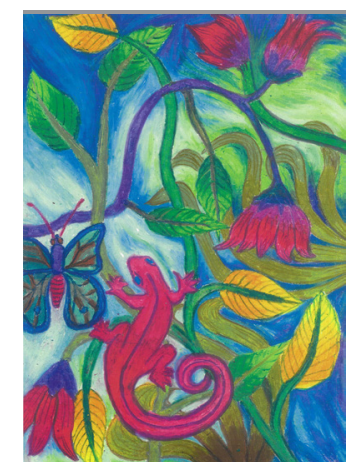

\begin{abstract}
Student agency is a hot topic in education in New Zealand at the moment. Future-focused learning and innovative learning environments seem to focus on student agency, but what does 'agency' actually mean? What does it look like for gifted students? And how do teachers to develop it in their students? In response to these questions, this position paper reviews the concept of student agency from an empirical base, asserts that curricula can be used to develop and support student agency, then looks at one example of a specialist curriculum for gifted learners that intentionally supports student agency.
\end{abstract}

\section{Position paper}

\section{Keywords:}

curriculum, gifted learners, student agency

\section{INTRODUCTION}

Student agency is inherent in the vision of the New Zealand Curriculum: "Young people who will be who will be confident, connected, actively involved, and lifelong learners." (Ministry of Education, 2007). It has been identified as a top trend in New Zealand education (Core Education, 2014; 2015), and is often noted as a goal for innovative learning environments (OECD, 2013). In numerous education-focused blogs and websites, student agency has been variously linked to ideas of 'voice and choice', having the power to act, self-management relating to e-learning, visible learning, and personal empowerment. But looking beyond the blogs and the buzz words, where does the concept of student agency come from and what does it really entail? This position paper will outline concepts around student agency as relating to gifted learners. More importantly, this position paper asserts that curriculum is the primary vehicle for developing agency in gifted learners and it will outline curriculum principles that support this.

\section{WHAT IS STUDENT AGENCY?}

Agency is defined in varied ways across a range of disciplines and is often most simply described as "... the socioculturally mediated capacity to act."
(Ahearn, 2001, p.110). Student agency refers to what a student thinks and does in a particular context at a particular time, and is, therefore, fluid, dynamic and subjectively experienced, rather than a fixed state of mind or an innate orientation to learning (Charteris, 2014; Dufva \& Aro, 2015; Priestley, Biesta, Phillippou \& Robinson, 2016).

Although the idea of student agency seems bound up with future-focused learning and innovative learning environments, it is not new. Dewey (1916) for instance, describes learners ideally as agents involved in determining their own outcomes. Agency is particularly relevant within gifted education, with concepts of self-direction and autonomy inherent in frequently espoused goals and curricula of gifted education (for example, Treffinger, 1975; Betts \& Kercher, 1999). Agency can be considered as a concept closely related to that of motivation, which has long been associated with gifted students and is identified as a key factor in a range of conceptions of giftedness. Renzulli's (1998) three-ring conception identifies task commitment, or motivation, as essential for the demonstration of 'gifted behaviour'. Gagne's Differentiated Model of Giftedness and Talent (2012) holds that gifts (natural abilities) can be transformed into talents (exceptional achievements) through a process that is moderated by personal and environmental influences, including motivation.

When viewed as a conceptual whole, there is only limited empirical evidence to suggest that agency influences student achievement. However, Gibbs and Poskitt's (2011) review found compelling evidence that conceptual components of agency, specifically self-efficacy, self-regulation and relatedness, impacted on achievement. Particularly in relation to gifted students, a sense of agency appears to be essential for high achievement. Mudrak and Zabrodska's (2015) multiple case-study of nine gifted young adults in the Czech Republic concludes that:

"The [gifted] participants who showed the highest level of achievement and motivation in early adulthood perceived themselves as 'agents of their learning' and made sense of their extraordinary outcomes as resulting from effortful, proper, and self-directed practice. 
Our findings indicate that a sense of agency is critical to maintaining gifted-level achievement through adolescence" (p.55, emphasis added).

Four inter-related concepts underpin the idea of student agency: self-efficacy, self-regulation, autonomy, and relatedness. These four concepts have been drawn from Bandura's social cognitive model (2008), Ryan and Deci's (2000) selfdetermination theory and Siegle and McCoach's (2005) Achievement Orientation Model. Each of these elements will now be briefly reviewed in turn with a focus on intellectually gifted learners, selecting literature from empirical research from an educational perspective with gifted learners, along with theoretical research with relevance to gifted learners and broader conceptual work where relevance to gifted students could be implied.

\section{Self-efficacy}

Academic self-efficacy is "... beliefs in one's capabilities to organize and execute the courses of actions required to manage prospective situations" (Bandura, 1997, p. 2). Self-efficacy beliefs are the most central element of student agency as they influence, and have an influence on, cognition, motivation and emotion (Bandura, 1997). Selfefficacy beliefs are specific to task at hand within a specific context, not more broadly globalised.

Self-efficacy beliefs influence a range of behaviours including attempting a task, putting effort into a task, persistence with a task, time spent on learning, willingness to continue in the face of difficulty, and range of actions taken (Rubenstein, Reis, McCoach \& Burton, 2012). These behaviours are linked to intellectual engagement more so than compliance with teacher directives (Hempel-Jorgensen, 2015).

Self-efficacy beliefs develop from four sources. In order of strength of influence from strongest to weakest, these are: perceptions of direct experiences; vicarious experiences (i.e. noticing the actions and accomplishments of others); persuasion, and physiological or emotional arousal (Bandura, 2008). Direct experience of success is more a powerful source of self-efficacy beliefs than persuasion, which appears to be the most commonly-used educational strategy. In terms of classroom application therefore, positive self-efficacy beliefs emerge in response to opportunities to take on challenging tasks, with appropriate supports that enable success (Burney, 2008).

Research supports the idea that gifted students inherently have more adaptive self-efficacy beliefs than non-gifted students. For example, in an early study, Zimmerman and Martinez-Pons (1990) investigated the self-efficacy beliefs relating to maths and verbal abilities of 90 gifted students and 90 non-gifted students in the US. They found that gifted students' self-efficacy beliefs in these areas were significantly higher than non-gifted students', concluding that, "These self-efficacy findings provide empirical support for anecdotal evidence that gifted students display extraordinary academic motivation and self-confidence" (Zimmerman \& Martinez-Pons, 1990. p. 57).

Conversely, it could be assumed that gifted students who also have learning, emotional, psychological or behavioural difficulties, that is, 'twice exceptional' students, show lower academic self-efficacy than non-twice-exceptional gifted students. However, Wang and Neihart's (2015) multiple case study of six twice-exceptional adolescents in Hong Kong found otherwise. These students expressed positive selfefficacy beliefs, which they largely attributed to their prior academic achievement, a strengths-focused programme, their high interest in their chosen area, and the strong external support from teachers, parents and peers. These findings clearly demonstrate the critical role of direct experience, coupled with appropriate educational and social supports, for building adaptive self-efficacy beliefs.

\section{Self-regulation}

Self-regulation is "... the degree to which students are metacognitively, motivationally, and behaviorally proactive regulators of their own learning process" (Zimmerman, Bandura \& Martinez-Pons, 1992, p. 664). The ability to self-regulate directly draws upon a learner's self-efficacy beliefs in order to set personal goals, to commit to taking action to achieve those goals, and to manage motivational states, the environment and social interactions as those goals are worked towards. Self-regulation, like self-efficacy, is highly contextually-specific and thus variable depending on the context.

As with self-efficacy, self-regulation develops through experience. Specifically, with regard to gifted students, Burney (2008) notes that the 'easy success' often experienced by gifted students is not conducive to them developing self-regulatory skills. Therefore, a related difficulty facing gifted students in developing self-regulation could be the lack of appropriately challenging material (Ruban \& Reis, 2006).

\section{Autonomy}

Autonomy is a fundamental psychological need, and is "... the need to be self-determined and to have a choice in the initiation, maintenance, and regulation of an activity." (Miserando, 1996, p. 2003). It is also often a stated goal of gifted education (for example Betts \& Kercher, 1999; Treffinger, 1975). Siegle, Rubenstein and Mitchell (2014) are among others who note that many school environments fail to allow autonomy in many respects. However, teachers can very simply enhance autonomy in their 
programmes by offering meaningful choices and appealing to student interests (Schraw, Flowerday \& Lehman, 2001). These are not by any means the only ways, as Phillips and Lindsay's (2006) multiple case study of highly-able students in the UK noted; highly-able students experienced greater autonomy by being allowed to work at their own pace, to conduct independent research, to find and use creative options, and to present their learning in varied ways. Gifted students' perceptions and experiences of autonomy are understandably varied (Miserando, 1996), and these perceptions and experiences influence selfefficacy beliefs (Lüftenegger et al., 2015).

\section{Relatedness}

Relatedness is the only explicitly social element of agency. The need for relatedness is "... the need to feel securely connected to others and the need to experience oneself as capable and worthy of love and respect" (Miserando, 1996, p. 203). Peer relatedness seems essential for gifted students, as Zimmerman and Martinez-Pons (1986) found that high-achieving students used peer support in learning twice as often as low-achieving students. For teacher-student relatedness, an autonomy-supportive relational style has been noted as important; this style including teacher empathy for students, acknowledgement of feelings and providing choice (Reeve, 2006; Baeten, Dochy \& Struyven, 2013).

\section{TAKING ACTION TO DEVELOP STUDENT AGENCY}

Bearing in mind that student agency is about what a student thinks and does in the particular context, it is important that classroom contexts are specifically oriented toward teaching for enabling agency. Words like ownership, responsibility, engagement, goal setting, and mindset are often used in relation to the question of how to develop student agency. It is simply not enough, however, to encourage students to be agentic, to give them permission to be agentic, or even to nag them into being agentic. Whilst a positive step towards enhancing agency is through specific instructional actions (Vaughn, 2014), a critical underpinning in these instructional actions is direction from curriculum. It is the fundamental position of this paper that curriculum is a primary vehicle for supporting student agency. Each of the four elements of agency discussed here can be directly influenced by the actions that teachers take through their enactment of curriculum.

The New Zealand Curriculum directs schools to design and review their own localised curriculum based on the New Zealand Curriculum (Ministry of Education, 2007; Education Review Office, 2011). Further, carefully planned and implemented provisions for meeting the needs of gifted students are recommended both nationally and internationally
(Education Review Office, 2008; Riley et al., 2004; Ministry of Education, 2012). VanTassel-Baska (2003) is among others who describe the logical rationale for a curriculum specifically for gifted students:

- All learners should be afforded opportunities to achieve to their fullest potential (Ministry of Education, 2007)

- Gifted learners have different cognitive, social, cultural and emotional needs to typical students, and therefore require a curriculum that is specifically differentiated to meet these (Ministry of Education, 2012)

- These needs are best served by a differentiated curriculum that involves challenge, acceleration, enrichment, sophistication, novelty, relevance, advanced content and higher order thinking (Clark, 2013; Hertberg-Davis \& Callahan, 2013; VanTassel-Baska \& Brown, 2001;2007).

One example of a localised curriculum for gifted learners that specifically aims to develop and enhance student agency is the New Zealand Centre for Gifted Education Curriculum for gifted learners (New Zealand Centre for Gifted Education, 2015). Like the New Zealand Curriculum, the New Zealand Centre for Gifted Education Curriculum is guided by a set of principles that link the broad vision of the curriculum to how it is formally enacted in a school. The principles of the New Zealand Curriculum "... put students at the centre of teaching and learning, asserting that they should experience a curriculum that engages and challenges them, is forward-looking and inclusive, and affirms New Zealand's unique identity" (Ministry of Education, 2007, p. 9). Similarly, the principles of the NZCGE curriculum are learnercentred and provide the foundation for specialised curriculum decision-making.

Four key principles of the NZCGE curriculum clearly support student agency and demonstrate how curricula can inform teacher actions to promote student agency.

- The principle of personalisation: To support student agency through personalization, teachers can personalise learning opportunities by providing choices in content, product and process, teach students how to make appropriately challenging and stimulating choices, uncover students' interests and use these to frame learning opportunities. Mudrak and Zabrodska's (2015) multiple-case study research found that high-achieving students who reported exercising agency said that they were able to follow their own interests and that their interests were an important part of their emerging identities.

- The principle of challenge: To support student agency through challenge, teachers can provide 
optimally challenging and stimulating learning experiences with advanced, complex content, teach with clear scaffolding to support to achieve success within these, and directly teach methods of self-regulation (behavioural, motivational and metacognitive). Stoeger and Ziegler (2010) maintain that self-regulatory strategies are easily directly teachable. Along with direct teaching, classrooms need to operate in a 'high-trust' model (Moore, 2017) using effective pedagogies (Ministry of Education, 2007), so that students can exercise their self-regulation.

- The principle of collaboration: To support student agency through collaboration, teachers can explicitly teach skills needed for relatedness, (student-student, student-teacher, student-teacherfamily), provide multiple and diverse opportunities for collaborative skills to be used in context, and directly highlight and discuss like-mindedness.

- The principle of strengths focus: To support student agency through a strengths focus, teachers can use the strengths, interests, talents and passions of students to direct teaching and learning. This supports engagement and, in turn, progress and achievement. A strengths focus links clearly to developing self-efficacy beliefs, self-regulation and autonomy.

A student's sense of agency, and their exercise of agency, is not a fixed attribute; rather, it is sensitive to time, place and context (Charteris, 2014). Within the NZCGE curriculum then, progress over time can be in part demonstrated by students through their increasing self-directedness in the pursuit and application of learning. This translates into practice as moving from reliant on teacher for direction and organisation to fully autonomous, based on Treffinger's (1975) model of self-direction. Through these understandings of what progress might look like, teachers are able to continue, in the longer term, to take action to develop and support growth in student agency.

\section{CONCLUSION}

This position paper reminds educators that student agency, or "... the socioculturally mediated capacity to act" (Ahearn, 2001, p.110) is fluid, dynamic, contextually-specific, and subjective. It is not a new idea, despite its current links with future-focused learning and innovative learning environments. When viewed as a concept related to motivation, student agency has a clear relationship with concepts of giftedness and therefore gifted education. Student agency has even been suggested as a critical element in the achievement of gifted students (Mudrak \& Zabrodska, 2015). In examining the four key concepts underlying agency, self-efficacy, self-regulation, autonomy and relatedness, we see relevance for gifted students. In supporting students to develop and experience agency in classroom contexts, it is not enough to remind, prompt, encourage or nag students. Teachers should primarily use the most powerful vehicle for change available to them - curriculum. Given the broad scope of the New Zealand Curriculum, coupled with its call to develop localized curriculum to meet the specific needs of groups of learners, the New Zealand Centre for Gifted Education has developed a curriculum for gifted students in New Zealand. This curriculum is underpinned by a set of principles that specifically support the self-direction and autonomy of gifted students, thereby using curriculum to develop agentic gifted learners. Curriculum can and should be used to develop agency in our learners.

\section{REFERENCES}

Ahearn, L.M. (2001). Language and agency. Annual review of anthropology, 30, 109-137.

Baeten, M., Dochy, F., \& Struyven, K. (2013). The effects of different learning environments on students' motivation for learning and their achievement. British Journal of Educational Psychology, 83, 484-501.

Bandura, A. (1997). Self-efficacy: The exercise of control. New York: Freeman.

Bandura, A. (2008). Toward an agentic theory of the self. In McInerney, D.M., Craven, R.G., \& Marsh, H.W. (Eds.), Self-processes, learning, and enabling human potential: Dynamic new approaches. (pp. 15-49). Information Age Publishing, Charlotte, NV.

Betts, G., \& Kercher, J.K. (1999). Autonomous learner model: Optimizing Ability. Australia: Hawker Brownlow Education.

Burney, V.H. (2008). Applications of social cognitive theory to gifted education. Roeper Review, 30, 130-139.

Charteris, J. (2014). Learner agency, dispositionality and the New Zealand curriculum key competencies. New Zealand Journal of Teachers' Work, 11(2), 175-186.

Clark, B. (2013). Growing up gifted: Developing the potential of children at school and at home. (8th edn.). Los Angeles, CA: Pearson.

Core Education. (2014). Trend 1: Learner agency [blog post]. Retrieved from http://www.core-ed. org/thought-leadership/ten-trends/ten-trends-2014/ learning-agency

Core Education. (2015). Trend 1: Learner agency [blog post]. Retrieved from http://core-ed. org/legacy/thought-leadership/ten-trends/tentrends-2015/ten-trends-2015-overview 
Dewey, J. (1916). Democracy and education. New York: McMillan.

Dufva, H., \& Aro, M. (2015). Dialogical view on language learners' agency: Connecting intrapersonal and interpersonal. In P. Deters, X. Gao, E.R. Miller, \& G. Vitanova (Eds.), Theorizing and analyzing agency in second language learning - interdisciplinary approaches (pp. 51-67). Bristol, UK: Multilingual Matters.

Education Review Office (2008). Schools' provisions for gifted and talented students: Good practice. Wellington: Education Evaluation Reports. Retrieved from http://www.ero.govt.nz/ publications/schools-provision-for-gifted-andtalented-students-good-practice/

Education Review Office (2011). Directions for learning: The New Zealand curriculum principles, and teaching as inquiry. Retrieved from http:// www.ero.govt.nz/publications/directions-forlearning-the-new-zealand-curriculum-principlesand-teaching-as-inquiry/introduction/

Gagne, F. (2012). Building gifts into talents: Brief overview of the DMGT 2.0. Retrieved from: http:// gagnefrancoys.wix.com/dmgt-mddt\#!dmgtenglish/ cabg

Gibbs, R., \& Poskitt, J. (2011). Student Engagement in the Middle Years of Schooling (Years 7-10): A Literature Review - Report to the Ministry of Education. Wellington, New Zealand: Ministry of Education.

Hempel-Jorgensen, A. (2015). Learner agency and social justice: What can creative pedagogy contribute to socially just pedagogies? Pedagogy, Culture \& Society, 23(4), 531-554.

Hertberg-Davis, H.L., \& Callahan, C.M. (2013). Defensible curriculum for gifted students - an introduction. In C. M. Callahan and H. L. HertbergDavis (Eds.), Fundamentals of gifted education: Considering multiple perspectives (pp. 259-262). New York, NY: Routledge.

Lüftenegger, M., Kollmayer, M., Bergsmann, E., Jöstl, G., Spiel, C., \& Schober, B. (2015). Mathematically gifted students and high achievement: The role of motivation and classroom structure. High Ability Studies, 26(2), 227-243.

Ministry of Education (2012). Gifted and talented students: Meeting their needs in New Zealand schools. Wellington: Learning Media.

Ministry of Education (2007). The New Zealand curriculum. Wellington, New Zealand: Learning Media.
Miserando, M. (1996). Children who do well in school: Individual differences in perceived competence and autonomy in above-average children. Journal of Educational Psychology, 88(2), 203-214.

Moore, L. (2017). The high-trust classroom: Raising achievement from the inside out. New York, USA: Routledge.

Mudrak, J., \& Zabrodska, K. (2015). Childhood giftedness, adolescent agency: A systematic multiple-case study. Gifted Child Quarterly, 59(1), 55-70.

New Zealand Centre for Gifted Education. (2015). Curriculum. Unpublished document.

OECD. (2013). Innovative learning environments. Educational research and innovation: OECD Publishing.

Phillips, N., \& Lindsay, G. (2006). Motivation in gifted students. High Ability Studies, 17(1), 57-73.

Priestley, M., Biesta, G., Phillippou, S., \& Robinson, S. (2016). The teacher and the curriculum: Exploring teacher agency. In D. Wyse, L. Hayward, \& J. Pandya (Eds.), The SAGE handbook of curriculum, pedagogy and assessment (pp. 187201). London, UK: SAGE Publications Ltd.

Reeve, J. (2006). Teachers as facilitators: What autonomy-supportive teachers do and why. The Elementary School Journal, 106(2), 225-238.

Renzulli, J.S. (1998). A decade of dialogue on the three-ring conception of giftedness. Roeper Review, 11(1), 18-25.

Riley, T., Bevan-Brown, J., Bicknell, B., Caroll-Lind, J., \& Kearney, A. (2004). The extent, nature and effectiveness of planned approaches in New Zealand schools for identifying and providing for gifted and talented students. Retrieved from http://www.educationcounts.govt.nz/publications/ schooling/5451

Ruban, L., \& Reis, S.M. (2006). Patterns of selfregulatory strategy use among low-achieving and high-achieving university students. Roeper Review, 28(3), 148-156.

Rubenstein, L.D., Reis, S.M., McCoach, B., \& Burton, M.G. (2012). A complex quest: The development and research of underachievement interventions for gifted students. Psychology in the Schools, 49(7), 678-694.

Ryan, R.M., \& Deci, E.L. (2000). Self-determination theory and the facilitation of intrinsic motivation, social development, and well-being. American Psychologist, 55(1), 68-78. 
Schraw, G., Flowerday, T., \& Lehman, S. (2001). Increasing situational interest in the classroom. Educational Psychology Review, 13(1), 211-244.

Siegle, D., \& McCoach, B. (2005). Making a difference: Motivating gifted students who are not achieving. Teaching Exceptional Children, 38(1), 22-27.

Siegle, D., Rubenstein, L.D., \& Mitchell, M.S. (2014). Honors students' perceptions of their high school experiences: The influence of teachers on student motivation. Gifted Child Quarterly, 58(1), 35-50.

Stoeger, H., \& Ziegler, A. (2010). Do pupils with differing cognitive abilities benefit similarly from a self-regulated learning training program? Gifted Education International, 26, 110-123.

Treffinger, D.J. (1975). Teaching for self-directed learning: A priority for the gifted and talented. The Gifted Child Quarterly, 19(1), 46- 59.

VanTassel-Baska, J. (2003). What matters in curriculum for gifted learners: Reflections on theory, research, and practice. In N. Colangelo and G.A.Davis (Eds.), Handbook of gifted education (3rd edn.) (pp. 174-183). Boston, MA: Pearson Education, Inc.

VanTassel-Baska, J., \& Brown, E.F. (2001). An analysis of gifted education curriculum models. In F.A. Karnes \& S.M. Bean (Eds.), Methods and materials for teaching the gifted (pp. 93-132) Waco, Texas: Prufrock Press Inc.

Vaughn, M. (2014). The role of student agency: Exploring openings during literacy instruction. Teaching and Learning, 28(1), 4-16.

Wang, C. W., \& Neihart, M. (2015). Academic self-concept and academic self-efficacy: Selfbeliefs enable academic achievement of twiceexceptional students. Roeper Review, 27(2), 63-73.

Zimmerman, B.J., Bandura, A., \& Martinez-Pons, M. (1992). Self-motivation for academic attainment: The role of self-efficacy beliefs and personal goal setting. American Educational Research Journal, 20(3), 663-676.

Zimmerman, B.J., \& Martinez-Pons, M. (1986). Development of a structured interview for assessing student use of self-regulated learning strategies. American Educational Research Journal, 23(4), 614-628.

Zimmerman, B.J., \& Martinez-Pons, M. (1990). Student differences in self-regulated learning: Relating grade, sex, and giftedness to selfefficacy and strategy use. Journal of Educational Psychology, 82(1), 51-59.

\section{AUTHOR PROFILE}

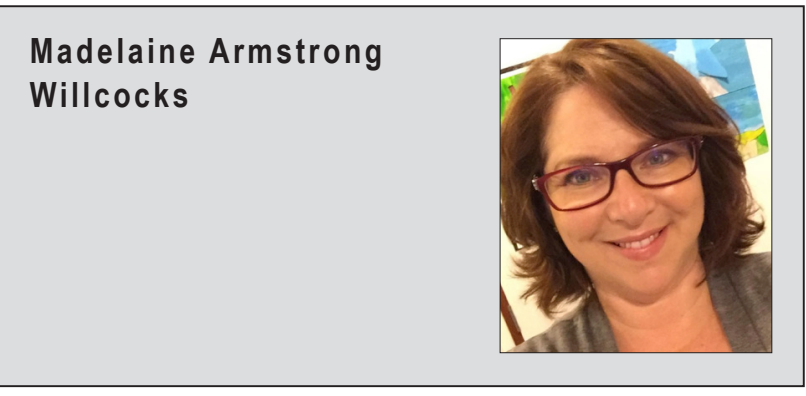

Madelaine Armstrong Willcocks is Regional Lead Teacher with the New Zealand Centre for Gifted Education, teaching MindPlus and Gifted Online programmes for gifted students. She is currently completing at Master of Specialist Teaching (Gifted and Talented) through Massey University.

Email: madelaine.willcocks@nzcge.co.nz 